\title{
Socio-Economic Importance of Tree Nursery Enterprises in Lagos State, Nigeria
}

\section{${ }^{1}$ EKO, OD; ${ }^{1}$ ADEDOKUN, MO; ${ }^{1}$ SOAGA, JA; ${ }^{1}$ OKOJIE, LO; ${ }^{* 2}$ ATANDA, TA; ${ }^{3}$ ABISOYE, TR}

\author{
${ }^{1}$ Department of Forestry and Wildlife Management, Federal University of Agriculture, Abeokuta, Nigeria \\ ${ }^{* 2}$ Forestry Research Institute of Nigeria, Jericho, Ibadan, Nigeria \\ ${ }^{3}$ World Ecological Concept Limited, Ibadan, Nigeria \\ *Corresponding Author Email: atandatoyeeb@gmail.com
}

\begin{abstract}
There is a growing interest to understand the role of tree nursery enterprises in Nigeria and the horn of Africa. Tree nursery enterprises, which are vital economic activities in major cities of Nigeria and particularly in the city of Lagos are not adequately studied and well documented. Therefore, this study seeks to fill a gap in understanding the socioeconomic importance and profitability potential of tree nursery enterprises. Multistage sampling technique with a 3-stage design was adopted in this study using aquantitative data collection techniques through the use of structured questionnaire administered to 120 nursery entrepreneurs. Data were analyzed using descriptive, inferential, and budgetary analysis. The result revealed that tree nursery entrepreneurs are literate, mostly male in their youthful age. Furthermore, the total annual revenue earned by the respondents was $\$ 1,712,222.22$ with a mean annual net income of $1,458,038.72$ while the return per naira invested was $\$ 5.71$. This shows that tree nursery enterprise is profitable in the study area. However, most entrepreneurs were faced with shortage of land for establishments of tree nursery in the study area. Therefore, appropriate actions in reducing cost of land lease/purchase are recommended to encourage new entrepreneurs and strengthen the sector's development.
\end{abstract}

\section{DOI: https://dx.doi.org/10.4314/jasem.v25i1.3}

Copyright: Copyright $($ C 2021 Eko et al. This is an open access article distributed under the Creative Commons Attribution License (CCL), which permits unrestricted use, distribution, and reproduction in any medium, provided the original work is properly cited.

Dates: Received: 02 October 2020; Revised: 26 November 2020; Accepted: 12 December 2020

Keywords: Entrepreneur, Environment, Nursery enterprises, Profitability, Socio-economic and Tree seedlings.

Locally in Nigeria, people are gradually becoming aware of the need for a beautiful, manageable and sustainable environment. This has accounted for the recent increase in attention and patronage that the ornamental tree nursery enterprises have observed in Lagos state and Nigeria as a whole (Bota, 2008). A major feature of the urban landscape is now the establishment of tree nurseries, springing up mainly along major roads and highways, abandoned lands, along streets, foot paths and even in private homes. This has created viable employment opportunities and means of livelihood for quite a number people thus improving the national economy (Asiedu, et al., 2012).A tree nursery is a well-managed site, designed to produce seedlings grown under favorable conditions until they are ready for planting out in the field (Dedefoet al., 2017). A tree nursery can be an informal, small scaled arrangement or a large commercial enterprise (Roshetkoet al., 2010). Nurseries vary in size, facilities (supplies, tools, equipment, etc.), types of seedlings produced, and operations. They also differ significantly in quality and quantity of planting stocks produced. The tree nursery enterprise involves the production and marketing of various plants including trees, shrubs, grasses, perennial and annual flowers, and fruit trees. In a tree nursery enterprise, plants are managed through various stages of production until they have grown to a saleable size (Larinde and Santus, 2014). Urbanization is a global phenomenon which is currently sweeping through developing countries like a wild fire. Many of such growing urban areas are in recent times are confronted with serious environmental challenges hence the need for tree planting in those areas is paramount. Lagos, Southwestern Nigeria, is one of the fast growing urban cities in the developing world which has been identified with resultant effects such as global warming, environmental degradation, poor urban health and low production of oxygen, compared to high quantity of carbon-dioxide generation from industries and automobiles among others (FAO, 2009). Therefore quite a number of strategies which include afforestation, urban agriculture, forest conservation and soft landscape planning among others have been put in place to improve urban green space for sustainable city ecological growth and development (Chaudhy and Gupta, 2009). Over the last two decades, the World Agroforestry Centre (ICRAF) has worked with hundreds of small-scale and large-scale tree 
nursery enterprises across the world. For example, in Indonesia and the Philippines to promote land rehabilitation, forest conservation, livelihood enhancement through creating opportunities like nursery establishment. Seedlings produced in nurseries are always used by the nursery operators themselves, individuals, and community organizations, farmer groups, government agencies, and non-government organizations, corporate or private customers. Nurseries may often provide income generating opportunities for the operators and enhance the social capital, technical capacity and leadership skills of communities (WAC, 2010).According to Babalola, (2008) a small-scale tree nursery is a self-employment business that can contribute to income generation and socio-economic development of the state but it has not been embraced because little or no information exists on costs and returns from the investment. However, tree nursery enterprises are beneficial because of the inherent financial gains, and the ecological benefits they confer. Tree plants provide revenue and income to Government and the people. Ecologically, they minimize disasters like soil erosion, environmental degradation, wind effects, and watershed obstructions (Frigeriet al., 2017). Therefore, this study was conducted to examine the socio-economic importance of tree seedlings in nursery enterprises in Lagos metropolis, Nigeria.

\section{MATERIALS AND METHODS}

Study Area:This study was carried out in the metropolitan areas of Lagos States. Lagos States has a total area of $3,577 \mathrm{~km}^{2}$ about 22 per cent of which is water. The Lagos metropolitan area is comprised of sixteen Local Government Areas (LGAs), including Amuwo-Odofin, Ojo,Ajeromi-Ifelodun, Agege, Alimosho, Ifako-Ijaiye, Ikeja,Kosofe, Oshodi-Isolo, Somolu, Lagos Island, Apapa, Eti-Osa, Lagos Mainland, Mushin, and Surulere. It lies within the geographical coordinate of $3.1^{0} \mathrm{E}$ to $3.4^{0} \mathrm{E}$ longitudes and $6.5^{\circ} \mathrm{N}$ to $6.8^{\circ} \mathrm{N}$ latitude, south-western, Nigeria (Soladoye and Oromakinde, 2013; Nkwunonwo, et al., 2016). The metropolis is regarded as one of the fastest growing cities in Africa and Nigeria's commercial nerve centre (Aluko, 2010). It is the most urbanized state in Nigeria with about $70 \%$ of the land area covered with towns and cities. (Olaleye, et al., 2015).The most disturbing aspects of the land-use changes in Lagos metropolis are the loss of virgin forests due to urbanization. Large hectares of mangrove swamps and other exotic vegetation have been lost to city development (Lagos State Ministry of Economic Planning and Budget, 2004). Vegetation and water cover have given way to an artificial urban landscape of concrete and tar (LURG, 2009).

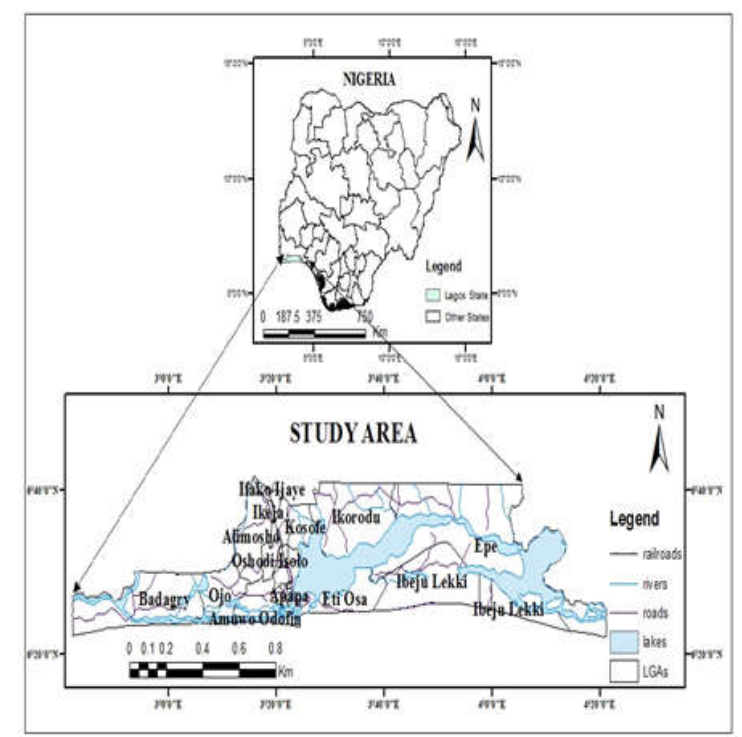

Fig 1: Map of Lagos State showing the study location: Source: Computed from Field Survey Data, 2017

Sampling Procedure and Sampling Size:A multistage sampling technique with a 3-stage design was used in selecting respondents for this study. The first stage involved the division of Lagos states into five major administrative areas (primary selection units). Each primary selection unit (administrative areas) represents a stratum. Secondly, the purposive selection of local government areas within the primary selection units with notable tree nursery enterprises was carried out. Finally, the third stage, respondents (nursery enterprises) was purposively selected from each local government area selected from the second stage given a total of 120 respondents selected for this study as shown in Table 1.

Table 1: Sampling Plan for the Study Area

\begin{tabular}{lll}
\hline Division & LGAs & $\begin{array}{l}\text { Number Of } \\
\text { Respondents }\end{array}$ \\
\hline 1. Ikeja & 1. Agege & \\
& 2. Alimosho & \\
& 3. IfakoIjaiye & 30 \\
& 4. Ikeja & 3 \\
& 5.Kosofe & 3 \\
& 6. Mushin & 20 \\
& 7. OshodiIsolo & \\
& 8. Shomolu & 10 \\
2. Lagos & 9. Apapa & 25 \\
& 10 EtiOsa & 5 \\
& 11. Lagos Island \\
& 12. Lagos Mainland & 8 \\
3. Badagry & 13. Surulere & 3 \\
& 14. Ajeromilfelodun & \\
& 15. AmuwoOdofin & 13 \\
& 16. Ojo & \\
4. Epe & 17. Badagry* & \\
& 18. IbejuLekki* & \\
5. Ikorodu & 19. Epe* & \\
\hline Total & 20. Ikorodu* & 120 \\
\hline \multicolumn{2}{c}{ Source: Computed from field survey data, 2017 }
\end{tabular}


Data Collection:In this study, both primary and secondary data were required for assessment. Primary data was collected through the use of structured questionnaire administered to respondents. The questionnaire contained information on socioeconomic characteristics of the respondents, types and prices of trees seedlings on demand, revenue from the sales of ornamental trees and costs incurred of trees seedlings in the study area. Secondary data used for this study were obtained from relevant publications which include: text-books, bulletins, periodicals, journals, annual reports, seminar papers, unpublished materials of relevance to the study, report documents from different ministries and even internet search to obtain the most recent information on the subject matter.

Analytical Techniques:Data collected from this study was analyzed with both descriptive and inferential statistics such as mean, mode, standard deviation, frequencies, and logit estimate. Budgetary analytical tool was used to assess the costs and returns of forest nursery seedling production in the study area (Muhammad-Lawal, et al., 2012) while profitability ratio was used to determine the Rate of Return on Investment (RORI).

Budgetary Analysis:The returns to farmer's labour and management is expressed in Naira per hectare $(\mathrm{N} / \mathrm{ha})$. Costs comprise both fixed and variable cost. Fixed Cost (FC) includes cost of depreciation charges on simple garden tools. While variable Cost (VC) include: cost of top soil, manure, seed/cuttings, agrochemical, labour, land rent and labour. Returns are revenues that accrue from the sale of produce.Generally, profit will be determined by:

$$
\text { Gross Profit (GP) }=\text { TR }-\mathrm{TVC} \ldots \text { (1) }
$$

Where; TR = Total Revenue ( $(\mathrm{N})$, is given by Py*Y; Py is the price/unit of the product, $\mathrm{Y}=$ Quantity/Output,TVC $=$ Total Variable Cost

$$
\text { Net Profit (NP) = GP }- \text { TFC ... (2) }
$$

Where; GP = Gross Profit; TFC = Total Fixed Cost; Total Cost $(\mathrm{TC})=\mathrm{TVC}+\mathrm{TFC} \ldots$ (3)

Profitability Ratio:Profitability ratio was adapted in analysing economic variables like Gross Income (GI), Net Income (NI) and Rate of Return on Investment (RORI) (Tee and Labo, 2010; Olaleye, et al., 2015). These tools are defined and computed as follows;

Net income (NI): This is defined as gross income (GI) less Gross cost (GC)

$$
\text { Mathematically: NI }=\text { GI }- \text { GC } \ldots
$$

Where; GI $=$ Total quantity of product sold over the period prevailing market price; $\mathrm{GC}=$ Total cost of production (cost of labour, fertilizer, water, transportation, polythene bags, topsoil).

Rate of return on investment (RORI):This depicts the level of profitability of an investment and is an important criterion in determining the choice of investment. It is determined using the following relationship:

$$
\text { RORI }=\frac{P R O F I T X 100}{T O T A L \operatorname{COST}}=\frac{T R-T C X 100}{T C} \ldots \ldots
$$

Where; Profit $\pi,=\mathrm{TR}-\mathrm{TC}$

$$
\mathrm{TC}=\mathrm{TVC}+\mathrm{TFC}
$$

Logit Analysis:It is stated as

$$
\mathrm{Y}=\alpha_{\mathrm{o}}+\alpha_{1} \mathrm{~W}_{1} \ldots \alpha_{\mathrm{n}} \mathrm{W}_{\mathrm{n}}
$$

$\mathrm{Y}=$ Profitability status $(1=$ Profit, $0=$ non-profit $) ; \mathrm{W}$ $=$ Independent variables $(\mathrm{i}=1$ to 7$)$

\section{RESULTS AND DISCUSSION}

Socio-Economic Characteristics of Nursery Entrepreneurs:The result of the socioeconomic distribution of respondents (Table 2) revealed that a high percentage of the tree nursery entrepreneurs in the study area were male $(65 \%)$ while $35 \%$ were female. The high involvement of male in tree nursery enterprise suggests that the business is not popular among the women in the study area.Larinde and Santus (2014) made similar observation in their study, male $(78.9 \%)$ and female (21.1\%), Adeduntan (2015) observed male (86\%) and female (14\%), Fakayodeet al. (2008) recorded male (85.2\%) and female (14.8\% ), Abegundeet al. (2009) recorded male (93.7\%) and female $(6.3 \%)$ while Khaguli (2007) observed men $(87 \%)$ and $(13 \%)$. This may be due to the fact that most of the operations performed in the nurseries are tedious and assumed to be men's work. The dominant age range among nursery entrepreneurs in the study area was between 30 and 39 years representing $36.7 \%$. This implies that nursery enterprises are composed of mainly youths. This agrees with Muhammed-Lawalet al. (2012) who reported the dominant age range of 2640 years for a similar study in Kwara State, Nigeria. Similarly, Asieduet al. (2012) reported that young and agile people of between $20-49$ years make up $75 \%$ of the respondent in his study of the nursery industry in Ghana. Olaleyeet al., (2015) reported in a similar study carried out in Lagos that the entire horticulturist 
are within the productive age, with about three-quarter (75\%) within the age bracket of 20 and 39 years. The results of studies conducted in Eldoret Municipality (Kenya) also correspond with the finding of this study that young people are beginning to venture into tree nursery enterprises, particularly in urban areas (RuttoandOdhiambo, 2017). More than half of the respondents $(83.3 \%)$ were married. This is supported by Larinde and Santus (2014), who reported $68.4 \%$ married nursery entrepreneurs. Also, Shalnim (2009) reported that $90 \%$ of the respondents in his study were married. However, Adeduntan (2015) claimed that $59.3 \%$ were single, $30.7 \%$ were married while $10 \%$ were divorced in a similar study carried out in Akure, Nigeria. There was high level of literacy among nursery entrepreneur in the study area as majority had undergone secondary education $(32.50 \%)$ and tertiary education $(24.16 \%)$.

Table 2: Socioeconomic Characteristics of Nursery Entrepreneur

\begin{tabular}{|c|c|c|c|}
\hline $\begin{array}{l}\text { Demographic } \\
\text { Characteristics }\end{array}$ & & $\mathrm{F}$ & $\%$ \\
\hline \multirow[t]{2}{*}{ Gender } & Male & 78 & 65 \\
\hline & Female & 42 & 35 \\
\hline \multirow[t]{5}{*}{ Age } & $<30$ years & 19 & 15.8 \\
\hline & $30-39$ years & 44 & 36.7 \\
\hline & 40-49 years & 28 & 23.3 \\
\hline & $50-59$ years & 19 & 15.8 \\
\hline & $>60$ years & 10 & 8.3 \\
\hline \multirow[t]{3}{*}{ Marital status } & Single & 15 & 12.5 \\
\hline & Married & 100 & 83.3 \\
\hline & Others & 5 & 4.2 \\
\hline Educational & No education & 16 & 13.33 \\
\hline \multirow[t]{5}{*}{ Level } & Primary school & 14 & 11.67 \\
\hline & Modern & 22 & 18.33 \\
\hline & Secondary school & 39 & 32.50 \\
\hline & $\mathrm{NCE} / \mathrm{HND} / \mathrm{BSC}$ & 25 & 20.83 \\
\hline & MSC/PHD & 4 & 3.33 \\
\hline Years of & $1-10$ years & 80 & 66.7 \\
\hline \multirow[t]{3}{*}{ Experience } & $11-20$ years & 26 & 21.7 \\
\hline & 21-30 years & 10 & 8.3 \\
\hline & $31-40$ years & 4 & 3.3 \\
\hline Business & Inheritance & 12 & 10 \\
\hline \multirow[t]{3}{*}{ Involvement } & Apprenticeship & 52 & 43.3 \\
\hline & $\begin{array}{l}\text { Formal/Professional } \\
\text { training }\end{array}$ & 7 & 5.8 \\
\hline & Personal Interest & 49 & 40.8 \\
\hline Land & By purchase & 4 & 3.33 \\
\hline \multirow[t]{3}{*}{ Acquisition } & Inheritance & 4 & 3.33 \\
\hline & Rent/Lease & 34 & 28.33 \\
\hline & Free gift & 78 & 65.00 \\
\hline \multirow{4}{*}{$\begin{array}{l}\text { Source of } \\
\text { Funds }\end{array}$} & Personal savings & 120 & 100 \\
\hline & $\begin{array}{l}\text { Help from family and } \\
\text { friends }\end{array}$ & - & - \\
\hline & Cooperative society & - & - \\
\hline & Bank loans & - & - \\
\hline
\end{tabular}

These facts indicate that the tree nursery enterprise could be embraced by educated youths that are either unemployed or under-employed in the society. This is in agreement with Larinde and Santus (2014) who had earlier reported that $60.5 \%$ had attended secondary school while $36.8 \%$ had attended tertiary education. This was further explained to have contributed greatly to the difference in the respondents' ability to manage their enterprise, how they kept their financial record of income and expenditure and how they raise their seedlings. Similarly, Shalnim (2009) reported that $80 \%$ of the ornamental plant producers he interviewed had attended tertiary institutions. This high literacy level of the respondents could affect their choice of inputs and also their willingness to adopt improved technologies. Majority of the respondents $(66.7 \%)$ had $1-10$ years of experience in the tree nursery enterprise, ascertaining the fact that popularity of the ornamental tree nursery enterprises is a recent development in Lagos State and Nigeria as a whole (Bota, 2008; Asiedu, et al., 2012). Furthermore, 65\% of respondents acquired temporary land for their nursery activities as free gift. This is contrary to Shalnim (2009) who reported that $100 \%$ of the respondents interviewed acquired their land through annual rent. All of the respondents interviewed in the study area funded their business through their personal savings as little capital was required to start the business.

Identification of Seedlings Raised in the Tree Nurseries Enterprises:The result of this study as revealed in Table 3 showed that forty one (41) different tree species were identified in the nursery enterprises in the study area. The categories of tree species include forest species, ornamental trees, palm species and fruit species. However, it was observed that the nursery entrepreneurs in the study area raise more of ornamental trees and shrubs and varieties of palm species which were in high demand for the purpose of beautification and landscaping of residential and corporate space. While very few of forest tree species and tropical fruits are available in their nurseries. This is partly due to the fact that very little is known of the usefulness of these tree species. Larinde and Santus (2014) reported that the categories of seedlings produced by the nursery operators interviewed include ornamental, horticultural, forestry, medicinal and agricultural seedlings. Muhammed-Lawalet al., (2012) reported that hedges, trees, palms, grasses are the predominant type of floricultural plants produce in the study area. Table 4 showed the frequency of occurrence of individual species. However, the family Palmea was dominant (36.59\%) among the species identified.

Costs and Return Analysis of Tree Nursery Enterprise:The total costs incurred during the production process were determined and the results obtained were presented in Table 5. 
Socio-Economic Importance of Tree Nursery.....

Table 3: Identification of species found in the private nursery in the study area

\begin{tabular}{|c|c|c|c|c|c|}
\hline $\mathbf{S} / \mathbf{N}$ & $\begin{array}{l}\text { Seedlings } \\
\text { Categories }\end{array}$ & Family & Common Name & Scientific Name & Form \\
\hline 1 & Forest & Moringaceae & Moringa & Moringaoleifera & Seedlings \\
\hline 2 & species & Pinaceae & Pine & Pinuscaribaea & Seedlings \\
\hline 3 & & Verbenaceae & Gmelina & Gmelinaarborea & Seedlings \\
\hline 4 & & Fabaceae & Flame of the Forest & Delonixregia & Seedlings \\
\hline 5 & & Meliaceae & Neem & Azardiractaindica & Seedlings \\
\hline 6 & Ornamental & Cupressaceae & Thuja & Thujaoccidentalis & Seedlings \\
\hline 7 & species & Combretaceae & Umbrella/Step tree & Terminaliarandii & Seedlings \\
\hline 8 & & Moraceae & Green Ficus & Ficusbeaghalensis & Seedlings \\
\hline 9 & & Moraceae & White Ficus & Ficusbenjamina & Seedlings \\
\hline 10 & & Annonaceae & Masquerade tree & Polyaithialongifolia & Seedlings \\
\hline 11 & & Asparagaceae & Cordyline & Cordylineaustralis & Seedlings \\
\hline 12 & & Asparagaceae & Yucca & Yucca filamentous & Seedlings \\
\hline 13 & & Araucariacea & Araucaria & Araucaria auricana & Seedlings \\
\hline 14 & Palm & Palmea & Oil palm & Elaesisguineensis & Seedlings \\
\hline 15 & species & Palmea & Queens palm & Syragrusromanzoffiana & Seedlings \\
\hline 16 & & Palmea & Royal Palm & Roystonearegia & Seedlings \\
\hline 17 & & Palmea & Cycas palm & Cycas revolute & Seedlings \\
\hline 18 & & Palmea & Kings palm & Archontophoenixcunningghamiana & Seedlings \\
\hline 19 & & Palmea & Golden palm & Dypsislutescens & Seedlings \\
\hline 20 & & Palmea & Fishtail palm & Caryota species & Seedlings \\
\hline 21 & & Palmea & Foxtail palm & Wodytiabifurcata & Seedlings \\
\hline 22 & & Palmea & Licuala palm & Licualagrandis & Seedlings \\
\hline 23 & & Palmea & Areca palm & Areca catechu & Seedlings \\
\hline 24 & Palm species & Palmea & Chinesse palm & Livostoniachinensis & Seedlings \\
\hline 25 & & Palmea & $\begin{array}{l}\text { Champagne bottle } \\
\text { palm }\end{array}$ & Hyophorbelagenicaulis & Seedlings \\
\hline 26 & & Palmea & Fan palm & Coccothrinaxspp & Seedlings \\
\hline 27 & & Palmea & Lady palm & Rhapisexcelsa & Seedlings \\
\hline 28 & & Streliziaceae & Traveller's & Ravanalamadagascariensis & Seedlings \\
\hline 29 & Fruit species & Palmea & Coconut & Cocosnucifera & Seedlings \\
\hline 30 & & Caricaceae & Pawpaw & Carica papaya & Seedlings \\
\hline 31 & & Anonaceae & Soursop & Annonamuricata & Seedlings \\
\hline 32 & & Oxalidaceae & Star fruit & Averrhoacarambola & Seedlings \\
\hline 33 & & Combretaceae & Almond & Terminaliacatappa & Seedlings \\
\hline 34 & & Anarcardiaceae & Cashew & Anacardiumoccidentale & Seedlings \\
\hline 35 & & Lauraceae & Avocado pear & Persea Americana & Seedlings \\
\hline 36 & & Rutaceae & Grape & Citrus paradise & Seedlings \\
\hline 37 & & Rutaceae & Sweet orange & Citrus sinensis & Seedlings \\
\hline 38 & & Myrtaceae & English apple & Syzygiumsamarangense & Seedlings \\
\hline 39 & & Anarcardiaceae & Mango & Mangiferaindica & Seedlings \\
\hline 40 & & Sapotaceae & African star apple & Chrysophyllum albidium & Seedlings \\
\hline 41 & & Myrtaceae & Guava & Psidiumguajava & Seedlings \\
\hline
\end{tabular}

The result revealed that the total cost (TC) of production of tree seedlings in the nurseries was $\$ 255,075.17$. The total variable (TVC) cost incurred was $\$ 250,382.50$ representing $98.16 \%$ of the total cost. While the total fixed cost (TFC) incurred was $\$ 4,692.67$ representing $1.84 \%$ of the total cost.The result from this study is similar to the findings of Shalnim (2009) who reported total variable cost and total fixed cost amounted to N288, 100 and N28, 204 respectively. Muhammed-Lawalet al., (2012) also reported that the total variable cost (TVC) incurred was $\$ 93,291.9$ while Tee and Labo (2010) reported that the production cost incurred in private nursery enterprises interviewed in Makurdi metropolis varied from $\$ 158,000$ to $\$ 820,000$.Furthermore, a gross margin of $1,462,731.39$ was revealed from the sales of seedlings within the study period. The result also showed that a nursery entrepreneur could earn average annual revenue of $\$ 1712222.22$ given mean annual net income of the respondents to be $1,458,038.72$. The profit margin percent of $55.8 \%$ was obtained while the return on naira invested was $\$ 5.71$. This is an indication that for every naira invested in tree seedlings production $\$ 5.71$ will be obtained in return. Olaleyeet. al., (2015) reported in a similar study in Lagos that the net annual income was $\$ 44,335,000.00$ and $\$ 27,865,000.00$ in the year 2008 and 2013 respectively with the ROI in 2018 and 2013 as $96.87 \%$ and $95.34 \%$. Shalnim (2009) recorded in a similar study in Jos metropolis that the total cost of producing the plants was N316, 304. The net farm income was found to be $\$ 351,196$ and return per naira invested N1.10. Tee and Labo (2010) also reported that the rate of return on nursery enterprises in Makurdi metropolis varied from $16.9 \%$ to $76.9 \%$, while, net income (NI) varied from $\$ 36250$ to $\$ 900$ 000. This is because 
seedlings in some nursery units were usually sold at relatively lower unit prices than in the other nursery units.However, the variation in the estimate may be due to the fact that the unit prices of seedlings are relatively higher in Lagos metropolis. Thus, it could be concluded that tree seedlings production in the study area was economically viable as the benefit-cost ratio obtained was 6.71 . This result is similar with (LarindeandSantus, 2014; Tee \&Labo, 2010) reported that, small-scale plant nursery enterprise is profitable

\begin{tabular}{|c|c|c|c|}
\hline $\mathrm{S} / \mathrm{N}$ & Family Name & Frequency & $(\%)$ \\
\hline 1 & Anarcardiaceae & 2 & 4.88 \\
\hline 2 & Annonaceae & 2 & 4.88 \\
\hline 3 & Araucariacea & 1 & 2.44 \\
\hline 4 & Asparagaceae & 2 & 4.88 \\
\hline 5 & Caricaceae & 1 & 2.44 \\
\hline 6 & Combretaceae & 2 & 4.88 \\
\hline 7 & Cupressaceae & 1 & 2.44 \\
\hline 8 & Fabaceae & 1 & 2.44 \\
\hline 9 & Lauraceae & 1 & 2.44 \\
\hline 10 & Meliaceae & 1 & 2.44 \\
\hline 11 & Moraceae & 2 & 4.88 \\
\hline 12 & Moringaceae & 1 & 2.44 \\
\hline 13 & Myrtaceae & 2 & 4.88 \\
\hline 14 & Oxalidaceae & 1 & 2.44 \\
\hline 15 & Palmea & 15 & 36.59 \\
\hline 16 & Pinaceae & 1 & 2.44 \\
\hline 17 & Rutaceae & 2 & 4.88 \\
\hline 18 & Sapotaceae & 1 & 2.44 \\
\hline 19 & Streliziaceae & 1 & 2.44 \\
\hline \multirow[t]{2}{*}{20} & Verbenaceae & 1 & 2.44 \\
\hline & Total & 41 & 100.00 \\
\hline
\end{tabular}

Source: Computed from Field Survey Data, 2017.

\begin{tabular}{lll}
\multicolumn{3}{c}{ Table 5: Summary of Cost and Return analysis } \\
\hline S/N & Variable & Total Amount \\
\hline 1 & Total Revenue & 1712222.22 \\
2 & Total Variable Cost & 250382.5 \\
3 & Total Fixed Cost & 4692.67 \\
4 & Total Cost $=$ (TFC+TVC) & 255075.17 \\
5 & Gross Margin (R+TVC) & 1462731.39 \\
6 & Net Income= (GM-TFC) & 1458038.72 \\
7 & RORI = (R-TVC)/TVC & 5.71 \\
8 & RORI (\%) & 571.26 \\
9 & BCR & 6.71 \\
\hline \multicolumn{2}{l}{ Source: Computed from Field Survey Data, 2017. }
\end{tabular}

Socioeconomic Factors Affecting Profitability of Tree Seedlings Production:Logit regression estimate was carried out to determine the socio-economic factors influencing revenue generation in nursery enterprises in the study area and the result are presented in Table 6. These factors include: Age (W1), Years of formal education (W2), Land acquisition (W3), Household size (W4), Years of experience (W5), Marital status (W6) and Gender (W7). The result showed the coefficient of age to be negative $(-0.174381)$ and significant at $5 \%$. This means that an increase in age by one year will decrease the total revenue by 0.17 . This is because the ability of nursery entrepreneurs to do tedious work diminishes as they lose their youthfulness. This is in line with the findings of Muhammed-Lawalet al. (2012).

More so, the coefficient of land acquisition was found to be negative $(-0.6899949)$ and significant at $5 \%$. This indicates that increase in cost of land acquisition process will reduce the total revenue by 0.70 . The coefficient of years of formal education is also negative (-0.19716) and not significant. This indicates that increase in level of education has negative influence on nursery productivity and thus insignificant. This could be as a result of the fact that operating a nursery enterprise is open to everyone regardless of their area of specialization in school and their level of education.

However, this is contrary to a priori expectation, as years of formal education is expected to have a positive influence on the productivity of the entrepreneurs. Furthermore, the coefficient of experience in nursery enterprise was positive $(0.0978015)$ and significant. Increase in experience in nursery enterprise by one year will result in increased productivity by $0.1 \%$.

This indicates that individuals who have mastered the business by virtue of the length of their years of experience tend to increase in productivity because they are conversant with certain trade secrets which new entrant into business may not be aware of. Gender is statistically insignificant this is because both male and female nursery entrepreneurs require the use of hired labour in order to enhance productivity.

Table 6: Summary of Logit Regression of Socio-Economic Factors Affecting Tree Seedlings Production

\begin{tabular}{llllll}
\hline Variables & Parameters & Coefficients & Standard Error & T-Value & R2 \\
\hline Constant & W0 & 7.845821 & 2.605557 & $3.01^{* *}$ & \\
Age & W1 & -0.174381 & 0.0485828 & $-3.59^{* *}$ & \\
Years of Formal Education & W2 & -0.019716 & 0.0526575 & $-0.37 \mathrm{~ns}$ & 0.1536 \\
Land Acquisition & W3 & -0.6899949 & 0.3366681 & $-2.05^{* *}$ & \\
Household size & W4 & 0.2248239 & 0.2097861 & $1.07 \mathrm{~ns}$ & \\
Years of experience & W5 & 0.0978015 & 0.0408834 & $2.39^{* *}$ & \\
Marital Status & W6 & -0.4454284 & 0.7033723 & $-0.63 \mathrm{~ns}$ & \\
Gender & W7 & 0.3412225 & 0.4724486 & $0.72 \mathrm{~ns}$ & \\
\hline \multicolumn{5}{c}{} \\
\multicolumn{5}{l}{ Source: Computed from field survey data, 2017.**Significant at } & $5 \%$
\end{tabular}


Conclusion: The result of this study showed that tree nursery enterprises are of great value to the economy of the Lagos metropolis, thus, needs to be encouraged and promoted as a means of livelihood among the people. However, most entrepreneurs were faced with shortage of land for establishments of tree nursery in the study area. Therefore appropriate actions in reducing cost of land lease/purchase are recommended to encourage new entrepreneurs and strengthen the sector's development.

\section{REFERENCES}

Abegunde, AA; Omisore EO; Oluodo, O F; Daniel, O (2009). Commercial horticultural practice in Nigeria: Its socio-spatial effects in Lagos city.Afr. J. Agri. Res. 4 (10), 1064-1072

Adeduntan, SA(2015). Contribution of some Ornamental Plants to the Socio-Economic Development of Urban Household in Akure Metropolis. Afr. J. Agri. Res 10(4):264-268

Aluko, OE (2010). The Impact of urbanization on housing development: The LagosExperience, Nigeria. Ethiop J. Environ. Stud. Manage. 3 (3), 64-74.

Asiedu, JBK;Owusu-Sekyere, JD; Taah, KJ; Van Der Puije GC; Ocloo, E(2012).The Nursery Industry In Ghana: Prospects And Challenges. Department of Crop Science and Department of Agricultural Engineering, University Of Cape Coast, Cape Coast, Ghana. J. Agric. Biol. Sci. 7 (6), 443-453.

Babalola, F (2008). Assessment of small-scale private nursery enterprises in Ibadan, Oyo State, Nigeria. Small-Scale Forestry, 7(3-4), 263-273.

Bota, MG(2008). Potential of horticultural nurseries in Ghana: A case study in the Ga North district of the Greater Accra region. B.Sc. Thesis. University of Cape Coast, Ghana. pp. 6-8, 24.

Chaudhry, P; Gupta, RK (2009). Urban forestry in arid region of India.Silviculture Division Arid Forest Res. Inst. Jodhpur. 12(10), 80-93

Dedefo, K; Derero, A; Tesfaye, Y; Muriuki, J (2017). Tree nursery and seed procurement characteristics influence on seedling quality in Oromia, Ethiopia. Forests Trees andLivelihoods, 26(2), 96-110.

Fakayode, BS; Adewumi, MO; Rahji, MAY;Jolaiya, JA (2008).Viability and Resource Use in Ornamental Plants Nursery Business in Nigeria. Europe. J. Soc. Sci. 6 (4), 19-28.
FAO(2009). The potential of urban forestry in developing countries: A concept paper, FAO, Rome.

Frigeri, J V; Krefta, SM; Paula AS;Germano, AD; Krefta, SC (2017). Environmental and socioeconomicbenefits of urban trees. In rLAS 2(1). https://www.research gate.net/publication/320957842_Environmental_ and_socioeconomic_benefits_of_urban_trees

Khaguli IE (2007) Comparative analysis of organisation of centralised and decentralised tree nursery development approaches in Kenya: a case of Nairobi and Kisumu districts. Msc. thesis, submitted to Egerton University, Njoro.

Lagos State Ministry of Economic Planning and Budget (2004). State of Lagos Megacity and other Nigerian Cities, a Report by the Lagos State Ministry of Economic Planning and Budget in collaboration with the Lagos State Ministry of Physical Planning and Urban Development. Pp 1973-1978.

UN-Habitat Office in Nigeria, the State NEPAD Committee and the Lagos Economic Summit Group (2006).Lagos Metropolitan Development and Governance Project. Pp 71-83.

Lagos Urban Reseach Group (LURG), (2009). Where is Lagos? - Geographic Position. Pp11-15.

Larinde, SL;Santus, R (2014).Assessment of Small Scale Private Plant Nursery Enterprise in Port Harcourt, Rivers State. Department of Forestry \& Wildlife Management, Faculty of Agriculture, University of Port Harcourt, Nigeria. Global J. Bio-sci.Biotechnol. 3 (3), 301-311.

Muhammad-Lawal, A; Adenuga, AH; Olatinwo, KB; Saadu, TA (2012).Economic Analysis of Floricultural Plants Production in Kwara State, North Central Nigeria. Asian J.Agric. Rural Develop. 2 (3), 373-380.

Nkwunonwo, CU (2013). Land use/Land cover mapping of the Lagos Metropolis of Nigeria using 2012 SLC-off Landsat ETM+ Satellite Images. Inter. J Sci. Eng. Res 4: (11), 1217-1222.

Olaleye DO;Abegunde, AA; Ebehikhalu, N (2015). Prospects and Challenges of Cities Micro Green Economy: A Study of Horticulture Practices in Lagos, Nigeria. Joseph Ayo Babalola University, 
Nigeria. Global J. Hum. Soc. Econ. 15 (2), 206215.

Roshetko JM, Tolentino EL Jr, Carandang WM, Bert omeu M, Tabbada AU, Manurung CE, Yao G (2010) Tree nursery sourcebook. Options in support of sustainable development. World Agroforestry Centre (ICRAF), SEA Regional Office and Winrock International, Bogor 7(3/4):333-352.

Rutto, GC; Odhiambo, KO (2017). Socio-economic importance of tree nurseries in eldoret municipality, UasinGishu County (Kenya). Afr. Environ. Rev.J.2 (2), 146-154.

Shalnim, NJ (2009). Resource Productivity in Ornamental Plants Production in Jos Metropolis, Nigeria. MSc thesis submitted to the Department of Agricultural Economics, University Of Nigeria, Nsukka..
Soladoye, O; Oromakinde, O (2013).Assessment of Tree Planting Efforts in Lagos Island Local Government Area of Lagos State, Nigeria; Department of Geography and Planning, Lagos State University, Ojo, Lagos, Nigeria. Resources Research 3 (4), 12-18.

Tee, NT;Labo, I (2010). Inventory and Economic Evaluation Of Seedling Species In Ornamental /Forest Nursery Enterprises In Makurdi Metropolis. Department of Social and Environmental Forestry University of Agriculture, Makurdi. Benue State, Nigeria. J. Res. For. Wildlife. Environ.2 (2), 99-104.

World Agro forestry Centre-ICRAF (2010).Tree nursery sourcebook-options in support of sustainable Development. Winrock international world Agroforestry centre ICRAF southeast Asia Regional Office.Pp978-979. 